якої виділяють соціально-мотиваційний, знаннєво-діяльнісний, ціннісно-креативний компоненти. Ефективне поєднання трьох компонентів визначає готовність директорів шкіл до використання Інтернет технологій у своїй роботі. Виокремлення критеріїв та їх показників дало змогу визначити рівні готовності директорів шкіл до використання Інтернет технологій у професійній діяльності: незадовільний; низький; задовільний; достатній; високий. Ми визначили організаційно-педагогічні умови професійного розвитку директорів шкіл для підготовки до використання Інтернет технологій у своїй роботі. 3 метою перевірки гіпотези дослідження нами проведено педагогічний експеримент, що проводився у три етапи на основі Львівського, Дніпропетровського, Волинського, Запорізького та Кіровоградського ІППО. Результати педагогічного експерименту свідчать про готовність директорів шкіл до використання Інтернет технологій у своій роботі. Розроблена авторська модель очного/дистанційного курсу «Використання Google-сервісів в управлінській діяльності керівника загальноосвітнього навчального закладу», ії методичне i програмне забезпечення перевірені експериментально. Обгрунтовано вибір сервісів Web 2.0 як основи освоєння директором школи Інтернет технологій.

Ключові слова: система неперервної педагогічної освіти, професійний розвиток, школа, професійна діяльність, Інтернет-технології, Інтернет-готовність, Web 2.0, IT-грамотність, IT-компетентність.

Submitted on March, 29, 2017

UDC: $37.013 .42: 377-026.42$

DOI: https://doi.org/10.24195/2414-4665-2017-4-22

Oksana Vasiuk,

Doctor of Pedagogy, associate professor, Department of Pedagogy, The National University of Life and Environmental Sciences of Ukraine, 15, Heroiv Oborony Str., Kyiv, Ukraine

\title{
FUTURE SOCIAL CARE TEACHERS' PROFESSIONAL FOCUS MATURITY
}

The paper aims to reveal the level of future social care teachers' professional focus maturity in terms of studying at higher educational institutions. The experiment involved 393 students of $1^{\text {st }}-4^{\text {th }}$ years of study majoring in "Social education" of Chernihiv National T. G. Shevchenko Pedagogical University (Chernihiv), The National University of Life and Environmental Sciences of Ukraine (Kyiv), Mykolayiv National University named after V. Sukhomlynskyi (Mykolaiv). The assessment of future social care teachers' professional focus was carried out by means of the method of expert evaluation. Besides, the method of the integral score calculation was also applied. The results were processed by means of the computer program "Statistics in education". The analysis of the research results has shown that the level of professional focus maturity of future social care teachers develops in the process of studying at a university. It can be explained by the fact that positive dynamics of students' professional focus maturity is influenced by the gradual increase of the number of disciplines of professional sphere and internship (practice) according to the year of study. The research results have shown that the level of the future social care teachers' professional focus maturity does not meet modern requirements which means that the process of its formation at higher educational institutions is carried out improperly. That is why it is necessary to develop a technique for the formation of future social care teachers' professional focus, which is planned to be performed in our further research works.

Keywords: professional focus, social care teacher, the level of maturity, higher educational institution, student.

\section{Introduction}

The work of future specialists in socionomic field, in particular, social care teachers, is focused on solving different kinds of human problems. It requires the higher educational institutions graduates to have profound knowledge, mature personal and professional skills. In this aspect the properly organized and managed professional training aimed at the formation of their professional focus is considered to be of particular importance.

Professional training of specialists in sociopedagogical field is studied in the following directions: didactic foundations of preparing students for sociopedagogical work (S. Kharchenko), management of social education quality (M. Yevtukh), formation of professional competence (V. Malinkina, V. Petrovych), professional focus (O. Moskaliuk), professional and pedagogical culture of future social care teachers (O. Homoniuk, T. Spirina), professional training of social care teachers in terms of lifelong education (V. Polishchuk), content of professional training of social care teachers in foreign higher educational establishments (Z. Aksiutina, S. Kohut, O. Pavlishak, O. Pryshliak), practical training of future socio-pedagogical workers in higher educational institutions (B. Shyfor, L. Jankins, Z. Falynska), professional focus on the occupation of socio-pedagogical sphere and pre-professional training of future social care teachers 
(Z. Hyliazova, S. Kohut, V. Polishchuk), preparing social care teachers for the organization of educational and leisure activities of students (S. Pashchenko).

Different aspects of preparing social care teachers for working with rural people were considered by O. Bezpalko (namely socio-pedagogical work with rural children and youth), M. Hurianova (theoretical and applied aspects of training social care teachers for rural environment), O. Lapa (preparing future social care teachers for practical work with rural youth), O. Mezhrytskyi (preparing students for sociopedagogical work in rural environment). At the same time, the issue of the formation of future social care teachers' professional focus still remains understudied.

The paper aims to reveal the level of future social care teachers' professional focus maturity in terms of studying at higher educational institutions.

The term "future social care teacher's professional direction" is considered as an integral personal quality which is characterized by the holistic system of needs and motives of humanistic-based socio-pedagogical activity, stable interest in future occupation, mature social values, scientific worldview and readiness to act in the society taking care its sociocultural and socio-economic characteristics.

\section{Research methods}

The assessment of future social care teachers' professional focus was carried out by means of Delphi method (the method of expert evaluation). We used the method of the integral score calculation. The results were processed by means of the computer program "Statistics in education" [3].

The experiment involved 393 students of $1^{\text {st }}-4^{\text {th }}$ years of study majoring in "Social education" of Chernihiv National T. G. Shevchenko Pedagogical University (Chernihiv / University 1), The National University of Life and Environmental Sciences of Ukraine (Kyiv / University 2), Mykolayiv National University named after V. Sukhomlynskyi (Mykolaiv / University 3).

The distribution of students by the institutions and years of study is presented in Table 3 .

\section{Discussion}

In the process of mastering the curriculum disciplines, students' professional thinking, motivation and interest in the future occupation, as well as social values are being developed, the abilities and skills of performing socio-pedagogical work are being formed. We believe that the professional focus of students majoring is sociopedagogical specialties develops according to the years of studying at a higher educational institution. In order to confirm this assumption, we have examined the development of the respondents' professional direction.

The method of expert evaluation was used to assess the level of future social care teachers' professional focus. Teachers (experts) having great teaching experience evaluated the respondents according to 16 indicators, whose significance has been determined (Table 1). The indicators are assessed according to the 5-point grading scale [1;2].

\section{Ranked list of weighting coefficients of the indicators denoting} future social care teachers' professional focus maturity

\begin{tabular}{|c|l|c|}
\hline$\#$ & \multicolumn{1}{|c|}{ Indicator } & $\begin{array}{c}\text { Significance } \\
\text { coefficient } P_{i}\end{array}$ \\
\hline 1 & The mature scientific worldview and readiness to work in rural environment & 0.88654 \\
\hline 2 & $\begin{array}{l}\text { The ability to use the acquired knowledge for solving different socio-pedagogical prob- } \\
\text { lems }\end{array}$ & 0.86024 \\
\hline 3 & The ability to assess and analyze person- and family-related socio-pedagogical problems & 0.7823 \\
\hline 4 & $\begin{array}{l}\text { The mastery of means, forms, methods, techniques of socio-pedagogical work with differ- } \\
\text { ent age groups and categories of clients }\end{array}$ & 0.766 \\
\hline 5 & Striving for self-development, adequate self-esteem & 0.71172 \\
\hline 6 & The desire to work and the need for professional development & 0.70092 \\
\hline 7 & $\begin{array}{l}\text { Responsible behavior when making decisions and understanding the level of the responsi- } \\
\text { bility }\end{array}$ & 0.65972 \\
\hline 8 & $\begin{array}{l}\text { Axiological attitude towards future occupation, mastering socially significant professional } \\
\text { values }\end{array}$ & 0.64358 \\
\hline 9 & Profound integrated knowledge in all educational disciplines & 0.6343 \\
\hline 10 & $\begin{array}{l}\text { Having knowledge and skills of personal intellectual development and professional think- } \\
\text { ing (critical thinking, flexibility of thinking) }\end{array}$ & 0.62312 \\
\hline 11 & Self-discipline, diligence, insistence, sociability & 0.60906 \\
\hline 12 & $\begin{array}{l}\text { The ability to use the appropriate methods of one's own psychic and psycho-physiological } \\
\text { state correction }\end{array}$ & 0.48988 \\
\hline 13 & Stable interest in socio-pedagogical activity and desire to deal with it & 0.4808 \\
\hline 14 & Expression of needs and motives of humanistic focus of socio-pedagogical activity & 0.38184 \\
\hline 15 & $\begin{array}{l}\text { Knowledge about social environment, its specificity, the consequences of the effect of } \\
\text { different personal socialization factors at meso-, macro- and mega-levels }\end{array}$ & 0.29575 \\
\hline 16 & The ability to adapt to modern socio-economic and working conditions & 0.2527 \\
\hline
\end{tabular}


The further data processing presented in expert sheets has made it possible to determine the result of the assessment of every indicator that is a product of the score expressed in conditional points $\left(\mathrm{x}_{\mathrm{i}}\right)$ multiplied by a weighting coefficient $\mathrm{P}_{\mathrm{i}}$. Then we calculated the integral score of future social care teachers' professional focus maturity according to the following formula:

$$
I O_{m}=\frac{x_{1} P_{1}+P_{2} w_{2}+\cdots+x_{n} P}{P_{1}+P_{2} \cdots+P_{n}},
$$

$\mathrm{x}_{1}, \mathrm{x}_{2}, \mathrm{x}_{\mathrm{n}}-$ scores of the indicators;

$\mathrm{P}_{1}, \mathrm{P}_{2}, \mathrm{Pn}-$ weighting factors of the indicators of fu- ture social care teachers' professional focus maturity.

The assessment of the level of future social care teachers' professional focus maturity was carried out by means of comparing the obtained integral score of every student with the boundary lines of integral scores of the levels, calculated with the help of the standard deviation method: 1 (high level) $-4.20-5.00$ points, 2 (sufficient level) - 3.60-4.19 points, 3 (medium level) - 3.00-3.59 points, 4 (low level) $-1.00-2.99$ points. The statistical processing of the results was performed by means of the computer program "Statistics in Education" (Table 2).

Table 2.

Average points of the students' professional focus maturity

\begin{tabular}{|c|c|c|c|c|}
\hline Higher educational & \multicolumn{4}{|c|}{ Years of study } \\
\cline { 2 - 5 } institution & 1 & 2 & 3 & 4 \\
\hline University 1 & 1.99 & 3.26 & 3.14 & 3.68 \\
\hline University 2 & 1.94 & 2.96 & 3.54 & 3.48 \\
\hline University 3 & 2.06 & 2.44 & 2.49 & 2.85 \\
\hline
\end{tabular}

The analysis of the results presented in Table 2 helps us to make a conclusion that the maturity level of future social care teachers' professional focus is increasing according to the year of study: the average score at University 1 according to the expert evaluation is 1.99 for the students of the $1^{\text {st }}$ year of study, 3.26 - for the students of the $2^{\text {nd }}$ year of study, 3.14 - for the students of the $3^{\text {rd }}$ year of study, and 3.68 - for the students of the $4^{\text {th }}$ year of study. It should be noted that the experts noticed the decrease of the level of professional focus maturity in the students of the $3^{\text {rd }}$ year of study. It can be explained by the fact that these respondents' academic performance is lower according to the results of their knowledge evaluation, as well as by higher demands of the experts to the assessment of these students according to the results of professional focus maturity. The gradual increase of the level of professional focus maturity is observed in the respondents of the University 2 (the average score increases from 1.94 for the $1^{\text {st }}$-year students to 3.48 - for the $4^{\text {th }}$-year students) and University 3 (the average score increases from 2.06 for the $1^{\text {st }}$-year students to 2.85 - for the $4^{\text {th }}$-year students). Therefore, among all the examined higher educational institutions, the students studying at University 1 have demonstrated the highest level of professional focus maturity. The lowest scores have been obtained according to the general integral score of professional focus maturity in the respondents studying at University 3 .

The median value also shows the positive dynamics of professional focus formation ("... the value of the property examined that has the same number of the sample elements on the left and on the right" [4, p. 221]). According to Table 3 , its values are 2 for the $1^{\text {st }}$-year students of University $1,3.3$ - for the $2^{\text {nd }}$-year students, 3.2 - for the $3^{\text {rd }}$-year students, and 3.75 - for the $4^{\text {th }}$-year students. Its value increases from 2 for the $1^{\text {st }}$-year students of University 2 to 3.6 for the $4^{\text {th }}$-year students; and from 2 to 2.8 for the students from $1^{\text {st }}$ to $4^{\text {th }}$ years of study at the University 3.

Statistical indicators of the students' professional focus maturity

\begin{tabular}{|c|c|c|c|c|c|c|c|c|c|c|c|c|c|}
\hline \multirow[t]{3}{*}{ \# } & \multirow{3}{*}{$\begin{array}{l}\text { Statistical } \\
\text { indicators }\end{array}$} & \multicolumn{12}{|c|}{ Higher educational institution } \\
\hline & & \multicolumn{4}{|c|}{ University 1} & \multicolumn{4}{|c|}{ University 2} & \multicolumn{4}{|c|}{ University 3} \\
\hline & & $\begin{array}{c}1^{\text {st }} \\
\text { year }\end{array}$ & $\begin{array}{l}2^{\text {nd }} \\
\text { year }\end{array}$ & $\begin{array}{c}3^{\text {rd }} \\
\text { year }\end{array}$ & $\begin{array}{l}4^{\text {th }} \\
\text { year }\end{array}$ & $\begin{array}{c}1^{\text {st }} \\
\text { year }\end{array}$ & $\begin{array}{l}2^{\text {nd }} \\
\text { year }\end{array}$ & $\begin{array}{c}3^{\text {rd }} \\
\text { year }\end{array}$ & $\begin{array}{l}4^{\text {th }} \\
\text { year }\end{array}$ & $\begin{array}{c}1^{\text {st }} \\
\text { year }\end{array}$ & $\begin{array}{l}2^{\text {nd }} \\
\text { year }\end{array}$ & $\begin{array}{c}3^{\text {rd }} \\
\text { year }\end{array}$ & $\begin{array}{c}4^{\text {th }} \\
\text { year }\end{array}$ \\
\hline 1 & Sample size & 26 & 36 & 23 & 26 & 39 & 37 & 24 & 37 & 16 & 48 & 35 & 46 \\
\hline 2 & Minimum & 1.5 & 2.3 & 1.9 & 1.9 & 1.3 & 1.8 & 25 & 2 & 1.6 & 1.5 & 1.4 & 1.7 \\
\hline 3 & Maximum & 2.5 & 4.2 & 4 & 4.6 & 2.4 & 3.9 & 4.5 & 4.4 & 2.6 & 3.4 & 3.6 & 4.1 \\
\hline 4 & Interval & 1 & 1.9 & 2.1 & 2.7 & 1.1 & 2.1 & 2 & 2.4 & 1 & 1.9 & 2.2 & 2.4 \\
\hline 5 & Sum & 51.9 & 117.7 & 72.3 & 95.9 & 75.9 & 109.6 & 85.1 & 128.8 & 33.1 & 117.3 & 87.3 & 131.1 \\
\hline 6 & Average & 1.99 & 3.26 & 3.14 & 3.68 & 1.94 & 2.96 & 3.54 & 3.48 & 2.06 & 2.44 & 2.49 & 2.85 \\
\hline 7 & Median & 2 & 3.3 & 3.2 & 3.75 & 2 & 3.1 & 3.45 & 3.6 & 2 & 2.45 & 2.4 & 2.8 \\
\hline 8 & Dispersion & 0.09 & 0.23 & 0.39 & 0.41 & 0.06 & 0.34 & 0.18 & 0.26 & 0.06 & 0.19 & 0.26 & 0.42 \\
\hline
\end{tabular}


It was extremely important for the research to assess the validity of the differences according to the results of expert evaluation to be sure that the data obtained are not random. By means of the computer program "Statistics in Education" we have built a matrix of comparing the scores distribution received by the students of the $1^{\text {st }}$ year of study according to the results of expert evaluation which shows their differences and common features.

The comparison of the distribution of the scores received by the students of the $1^{\text {st }}$ year of study according to the results of expert evaluation by the Mann-Whitney $U$ test allows us with $95 \%$ probability to state that the distribution of the scores which characterize the $1^{\text {st }}$-year students' professional focus has no significant differences. In particular, the empiric values of the Mann-Whitney U test are smaller $(0.6087 ; 0.6826 ; 1.2601)$ than its critical value (1.96) when comparing the distribution of the scores of the $1^{\text {st }}$-year students. It can be explained by the fact that all $1^{\text {st }}$-year students in the examined universities study in identical conditions.

The comparison of the distribution of the scores received by the students of the $2^{\text {nd }}$ year of study according to the results of expert evaluation by the Mann-Whitney $\mathrm{U}$ test allows us with $95 \%$ probability to state that the distribution of the scores which characterize the $2^{\text {nd }}$-year students' professional focus has significant differences. In particular, the empiric values of the Mann-Whitney $U$ test are greater $(2.2233 ; 4.0153 ; 6.187)$ than its critical value (1.96) when comparing the distribution of the scores of the $2^{\text {nd }}$-year students.

The comparison of the distribution of the scores received by the students of the $3^{\text {rd }}$ year of study according to the results of expert evaluation by the Mann-Whitney $\mathrm{U}$ test are almost the same as for the $2^{\text {nd }}$-year students. In particular, the empiric values of the Mann-Whitney U test are greater $(2.0433 ; 3.640 ; 5.506)$ than its critical value (1.96).

The comparison of the distribution of the scores received by the students of the $4^{\text {th }}$ year of study according to the results of expert evaluation by the Mann-Whitney U test gives us reasons to state that the indices of $4^{\text {th }}$-year students' professional focus have significant differences in University 2 and University 3, namely the empiric values of the Mann-Whitney $U$ test are greater (4.2785; 4.584) than its critical value (1.96). The validity of the differences of the samples compared is $95 \%$. The distribution of the scores which characterize the professional focus of the $4^{\text {th }}$-year students of University 1 and University 2 have not significant differences. In particular, the empiric values of the Mann-Whitney $U$ test are smaller (1.570) than its critical value (1.96). It can be explained by different conditions of the educational process organization in the examined universities.

Based on the determined levels of future social care teachers' professional focus maturity and the research results we have differentiated the respondents according to the following levels: low, sufficient, medium, and high.

Then with the help of the technique of integral score calculation the differentiation of three groups of students (depending on the universities where they study) according to the levels of their professional focus maturity was performed (Table 4).

Table 4.

Differentiation of the university students according to the levels of their professional focus maturity (\%)

\begin{tabular}{|c|c|c|c|}
\hline \multirow{2}{*}{ Level } & \multicolumn{3}{|c|}{ Higher educational institution } \\
\cline { 2 - 4 } & University 1 & University 2 & University 3 \\
\hline High & 7.14 & 3.76 & 0.7 \\
\hline Sufficient & 25.03 & 21.58 & 6.89 \\
\hline Medium & 35.69 & 30.87 & 18.62 \\
\hline Low & 32.15 & 43.79 & 73.79 \\
\hline
\end{tabular}

The analysis of the results received shows that the students studying at University 1 have the most mature professional focus. In particular, there are the greatest number of students in this university whose level of professional focus maturity is the highest, namely $7.14 \%$. There are half less students with the high level of professional focus maturity in University $2-3.76 \%$. And only $0.7 \%$ of the respondents from University 3 have the high level of professional focus maturity.

\section{Conclusions}

The analysis of the research results has shown that the level of professional focus maturity of future social care teachers develops in the process of studying at a university. It can be explained by the fact that positive dynamics of students' professional focus maturity is influenced by the gradual increase of the number of professional disciplines and practice.
Besides, it should be noted that the greatest number of the students from all the examined universities have low and medium level of professional focus maturity (about 70-90\%). The number of the students with the sufficient level of professional focus maturity is $6.89 \%$ in University 3 and $25 \%$ in University 1 . The lowest results were detected in the respondents from University 3. The results obtained mean that there are certain differences in educational process organization in the examined higher educational institutions and the insufficient attention to the formation of future social care teachers' professional focus. The students studying at Chernihiv National T. G. Shevchenko Pedagogical University have the most mature level of professional focus, compared to the other respondents.

Thus, the research results show that the level of the future social care teachers' professional focus maturity 
does not meet modern requirements which means that the process of its formation at higher educational institutions is carried out improperly.

\section{REFERENCES}

1. Asherov, A. T. (2002). Podgotovka, ekspertiza $i$ zashchita dissertatsii: ucheb. posob. [Writing, assessing and defending thesis: textbook]. Kharkov: UIPA [in Russian].

2. Asherov, A. T., Logvinenko, V. G., Fedorov, I. V. (2007). Razvitie poznavatelnoi samostoiatelnosti studentov pri izuchenii distsiplin kompiuternogo tsikla [Development of cognitive independence of students when studying computer science disciplines]. Moscow: MADI (GTU); Kharkov: UIPA [in Russian].

\section{ЛІТЕРАТУРА}

1. Ашеров А. Т. Подготовка, экспертиза и защита диссертации : учеб. пособ. / А. Т. Ашеров. - Харьков : УИПА, 2002. - 135 с.

2. Ашеров А. Т. Развитие познавательной самостоятельности студентов при изучении дисциплин компьютерного цикла / А. Т. Ашеров, В. Г. Логвиненко, И. В. Федоров. Москва : МАДИ (ГТУ); Харьков : УИПА, 2007. - 189 с.
That is why it is necessary to develop a technique for the formation of future social care teachers' professional focus, which is planned to be performed in our further research works.

3. Kompiuternaia programma «Statistika v pedagogike» [Computer program "Statistics in education"]. $\quad$ Retrieved from: http/l www.mtas.ru/uploads/stat.zip. [in Russian].

4. Luzan, P. H., Sopivnyk, I. V., Vyhovska S. V. (2010). Osnovy naukovo-pedahohichnykh doslidzhen : navch. posib. [Bases of scientific researches in education: textbook]. $2^{\text {nd }}$ ed. rev. Kyiv: NAKKKiM [in Ukrainian].

3. Компьютерная программа «Статистика в педагогике» [Электронный ресурс]. - Режим доступа: http : // www.mtas.ru/uploads/stat.zip.

4. Лузан П. Г. Основи науково-педагогічних досліджень : навч. посіб. / П. Г. Лузан, І. В. Сопівник, С. В. Виговська. - [2-ге вид., доп.]. - Київ : НАККKiM, 2010. -272 c.

Оксана Вікторівна Васюк, доктор педагогічних наук, доцент кафедри педагогіки, Національний університет біоресурсів і природокористування України, вул. Героїв оборони, 15, м. Київ, Украӥна

\section{СФОРМОВАНІСТЬ ПРОФЕСІЙНОЇ СПРЯМОВАНОСТІ МАЙБУТНІХ СОЦІАЛЬНИХ ПЕДАГОГІВ}

У статті проаналізовано стан сформованості професійної спрямованості майбутніх соціальних педагогів у вищих навчальних закладах. Під поняттям “професійна спрямованість майбутнього соціального педагога" - інтегральна якість особистості, що характеризується цілісною системою потреб і мотивів гуманістично спрямованої соціально-педагогічної діяльності, стійким інтересом до майбутньої професії, сформованими соціальними цінностями, розвинутим науковим світоглядом та готовністю продуктивно діяти в соціумі з урахуванням його соціокультурних і соціально-економічних характеристик. У дослідженні взяли участь 393 студенти 1-4 курсів напряму підготовки "Соціальна педагогіка" Чернігівського національного педагогічного університету імені Т. Г. Шевченка (м. Чернігів) (ВН3 1), Національного університету біоресурсів і природокористування України (НУБіП України) (м. Київ) (ВН3 2), Миколаївського національного університету імені В. О. Сухомлинського (м. Миколаїв) (ВН3 3 ). За допомогою методу експертних оцінок здійснено оцінювання респондентів за проранжованим рядом показників рівня сформованості професійної спрямованості. Розраховано інтегральну оцінку $\mathrm{IO}_{\mathrm{m}}$ сформованості професійної спрямованості кожного студента. На основі визначених рівнів сформованості професійної спрямованості майбутніх соціальних педагогів та результатів експерименту диференційовано студентів за такими рівнями: низький, достатній, середній, високий. Показники інтегральної оцінки $\mathrm{IO}_{\mathrm{m}}$ дозволили здійснити поділ студентів досліджуваних груп трьох вищих навчальних закладів за рівнями сформованості професійної спрямованості. Результати оброблялися за допомогою комп’ютерного продукту «Статистика в педагогіці». У результаті експерименту 3'ясовано динаміку професійної спрямованості студентів під час навчання у ВНЗ. Серед навчальних закладів студенти ВНЗ 1 продемонстрували найвищі результати в аспекті сформованості рівнів професійної спрямованості. У більшості респондентів кожного із трьох досліджуваних ВНЗ рівень сформованості професійної спрямованості не відповідає сучасним вимогам, оскільки понад 70\% студентів продемонстрували низький, і лише близько $8 \%$ високий рівні сформованості професійної спрямованості. Це свідчить про те, що процес формування професійної спрямованості майбутніх соціальних педагогів у ВНЗ здійснюється недостатньо цілеспрямовано і несистемно.

Ключові слова: професійна спрямованість, соціальний педагог, показник сформованості, вищий навчальний заклад, студент.

Submitted on March, 30, 2017 